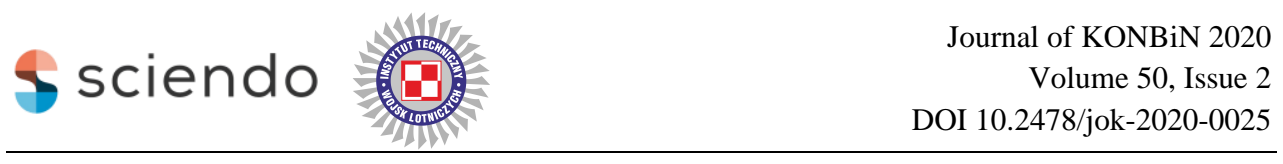

\author{
Olimpia KUNERT \\ Military University of Aviation (Lotnicza Akademia Wojskowa)
}

\title{
REVERSE LOGISTICS AS A BURDEN IN THE CONTEXT OF AIRPORT
}

\section{Uciążliwość logistyki zwrotnej odpadów w kontekście bezpieczeństwa portu lotniczego}

\begin{abstract}
From the perspective of management, reverse logistics constitutes a certain burden to the functioning of airports. In the light of the State Transport Policy for 2006 2025, the operation of such facilities in a manner that will enable the fulfillment of specific reverse logistics needs without causing threats becomes an important objective of airport security. The focus of reverse logistics is waste flows, and, in addition to returns, reverse logistics also takes into account the protection of natural resources and minimization of pollution. Reverse logistics is characterized by the fact that the direction of the flow of goods that have been partially utilized, but still have a certain value that can be recovered, is opposite to that in a traditional distribution channel. The article focuses on public security from the perspective of environmental threats, on the basis of the results of research studies in waste reverse logistics, at selected Polish civil airports, as a potential risk factor for ground operations in air transport.
\end{abstract}

Keywords: airport, environmental protection, waste, logistics

Streszczenie: Z punktu widzenia zarządzania, logistyka zwrotna stanowi swoiste utrudnienie dla funkcjonowania portów lotniczych. Eksploatacja takich obiektów w sposób umożliwiajacy realizacje określonych potrzeb logistyki zwrotnej $i$ niepowodujacy zagrożen, $w$ świetle Polityki transportowej państwa na lata 2006-2025 staje się istotnym celem bezpieczeństwa portu lotniczego. Logistyka zwrotna, skupia się na przepływach odpadów, która obok problematyki zwrotów, uwzględnia również ochronę zasobów naturalnych i minimalizowanie zanieczyszczeń. Charakteryzuje ja przeciwny niż $w$ tradycyjnym kanale dystrybucji kierunek przepływu dóbr, które zostały w jakimś stopniu zużyte, lecz posiadaja pewna wartość, która można odzyskać. W artykule przedstawiono wyniki badań w obszarze czynności logistycznych zwiazanych z logistyka zwrotna odpadów na wybranych polskich lotniskach cywilnych jako czynnika potencjalnego ryzyka dla operacji naziemnych transportu lotniczego.

Słowa kluczowe: port lotniczy, ochrona środowiska, odpady, logistyka 


\section{Introduction}

According to the Waste Act (Act of 27 April 2001 on Waste - Journal of Laws No. 62, Item 628), waste is defined as "... any substance or object which its holder intends to dispose of, disposes of, or is obliged to dispose of." Airport waste comprises all by-products resulting from aircraft operation, passenger-related activities, and the activities of airport employees, which are not useful at the location and time in which they were created, harmful or burdensome to the environment, or which may lead to its degradation.

Waste management obligation covers many logistic functions such as waste collection, storage and transshipment, as well as waste disposal processes [10,13]. Reverse logistics of waste is situated within management processes [2], which in the case of airports has a direct impact on the security of their operation, both during and after the activities of the airport services in individual facilities.

The term reverse logistics $[1,8,9]$ is not the only one used for this process. There are also other terms used in literature, such as; secondary logistics, green logistics, environmental logistics, and recirculation logistics. Each of these concepts, however, has a specific emphasis, e.g. environmental logistics is mainly focused on eliminating the negative impact of waste on the natural environment and is looking for optimum logistic solutions with this respect, whereas recirculation logistics is more focused on the recycling of waste. $[2,6,12]$. For the purpose of analyzing the impact on airport security, the term of reverse logistics was adopted as that term is the best to reflect the problem of disturbances to the airport operation.

Modern airports render a wide variety of services, where airport management services are clearly distinguished from ground handling services. Moreover, airport infrastructure management services are considered to be superior to the management of ground handling services. In the practical application of EU competition rules, it is assumed that "the role of airports is to manage and maintain, and sometimes even to build airport infrastructure". Airports must make their infrastructure available to users and must ensure its effective functioning, in particular by organizing and coordinating all operations performed at the airport.

Therefore, airport management services include such services as: management and maintenance of runways, taxiways, aprons [11], as well as the approach guidance system for civil aircraft. The European Commission has pointed out that airport management includes the following activities: authorizing suppliers to provide specific categories of assistance, supervising the movement of vehicles and personnel, organizing activities requiring the utilization of jointly used devices, and monitoring the quality of ground handling services provided to airlines ${ }^{1}$.

Reverse logistics viewed as a process includes planning, implementing, and controlling the effective waste flow to collection points in order to recover its value or to manage it properly. This puts airport managers in the difficult position of looking for

1 Pkt 54 i 58 dec. KE nr 98/513/WE from11 June,1998, Alpha Fight Services/Aéroports de Paris. 
compromises between the obligation to ensure the proper functioning of airports and the need to meet the growing requirements concerning environmental protection at airports and in their immediate vicinity.

\section{Reverse logistics in the aspect of airport operation security}

In the geographical environment of an airport, there are facilities whose function is to meet various needs of airport services. The operation of such facilities is becoming a significant objective for airport operation security. The needs of reverse logistics concentrate on waste flows, which, apart from returns, must also take into consideration the protection of natural resources and minimizing pollution in such a way that will not pose a threat to the environmental security of the airport. Therefore, the security of airport operation is also dependent on environmental security.

All waste generated at the airport is subject to quantitative and qualitative recording in accordance with applicable, particularly local, law. Waste generated at the airport must be sorted upon collection, and then stored in specially designated and marked storage locations. After collecting the appropriate amount, the waste is then sent for recycling or disposal. The airport usually transfers all the waste it generates to companies licensed by the competent authority for conducting waste management operations (recycling, disposal, storage, collection, and transport). Airport-generated waste includes hazardous waste and packaging of hazardous substances coming from aircraft de-icing operations, sewage, process waste, cut grass from green areas, and a whole range of municipal waste. This also applies to post-accident waste, i.e. waste generated during rescue or firefighting operations at the airport.

The airport is obliged to collect and sort municipal waste both among employees and passengers, as well as guests using its services. At the same time, all logistic activities related to that cause disturbances to the operation of individual airport facilities and, what it involves, burden decision-makers in the airport security management system.

In reverse logistics of airport waste, an important issue is the approach to this problem, which could be: finding a way to save money [7] or merely eliminating the waste-related problems. In the first case, the objective of reverse logistics is to recover recyclable materials, which can be a source of profits for the company, in the second case it is just to comply with the statutory obligation.

Two aspects can be distinguished in the security of airport facility operation; internal security and external security - depending on where the facilities are located, and where the threats originate from, namely:

- internal security is defined as a lack of threat generated by a given facility to the airport using the facility to meet its own needs, 
- external security means that no threat is generated by a given facility to other entities or facilities in its vicinity.

Reverse logistics exerts an influence on the security of airport facility use in the aspect of their operation, both internally - in accordance with their purpose, as well as externally, as being part of the airport's functional infrastructure and its protection zone. This dependence means that in the area of ecology we must seek the most sustainable activities with strong cultural and organizational base leading to an increase in environmental competences.

\section{Environmental potential of an airport}

An airport can build its environmental competences from scratch, it may develop the environmental potential it already possesses, and it may also assess an impact of its environmental potential or competences on the company value. The factors building environmental competences are present in the set of intangible assets [4].

Environmental potential is defined as the ability to attain environmental efficiency as a result of the most favorable association of airport operational tasks with maintaining ecological balance. Environmental potential is built from endogenous sources, i.e. sources inherent in the enterprise; in the structure of services, in the scope of their operation and effectiveness without external factors.

Factors which affect the environmental potential are present in various areas of the airport's operation, hence the basic task is to isolate them and raise them to such a level of activity that they may constructively influence the construction of environmental potential - this is the so-called "self-organization level" [5].

For the purposes of examining ecological competences at Polish civil airports, a fourlevel scale for assessing the degree of correlation between elements in the sets was adopted, namely:

$1^{\mathrm{o}}$ - uncorrelated factors,

$2^{\circ}-$ weakly correlated factors,

$3^{\mathrm{o}}$ - correlated factors,

$4^{\mathrm{o}}$ - strongly correlated factors.

The degree of correlation of factors can be determined by examining how many elements of a given set share at least one correlation with elements of the other set. The degree of correlation between the entire sets will be the arithmetic mean of the number of 
correlations between the sum of elements from a given set and the sum of elements from other sets.

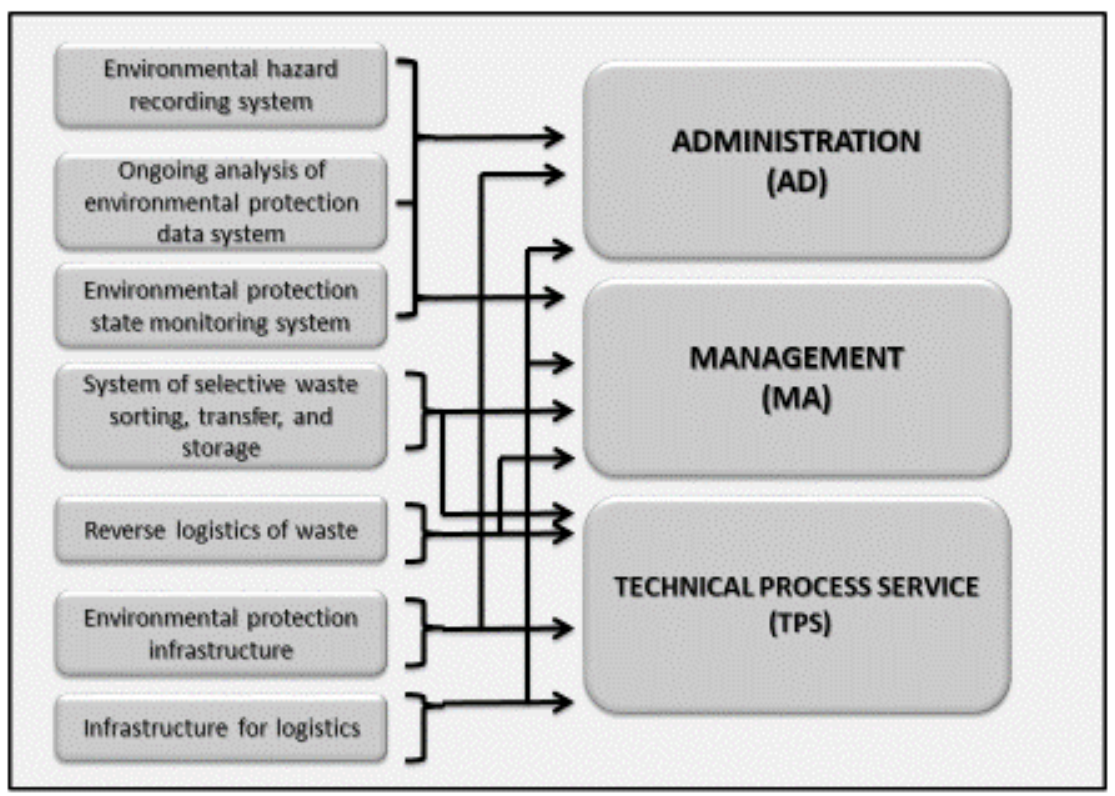

Fig. 1. Influence areas of factors from endogenous sources creating the environmental potential of the airport

\section{Identification of environmental orientation of Polish civil airports}

As a result of the research, technical and organizational identification concerning ecology was performed at three Polish airports using the proprietary method of industrial diagnostics - the "lens method", which consists in the application of a multi-faceted approach to the research area, development of interdependent criteria of assessment, and conducting objective and subjective research studies concerning a given company.

Problems to be solved according to the method adopted are viewed from three different perspectives:

- internal - the functioning of the airport through technical and organizational audit of airport facilities which participate in reverse logistics;

- management staff - reported problems regarding security disturbances related to the implementation of reverse logistics;

- market - research concerning airport service providers involved in reverse logistics. 
Problems that are ultimately identified as "relevant to airport security" are found in the strengthened field from the three different sources of information mentioned above.

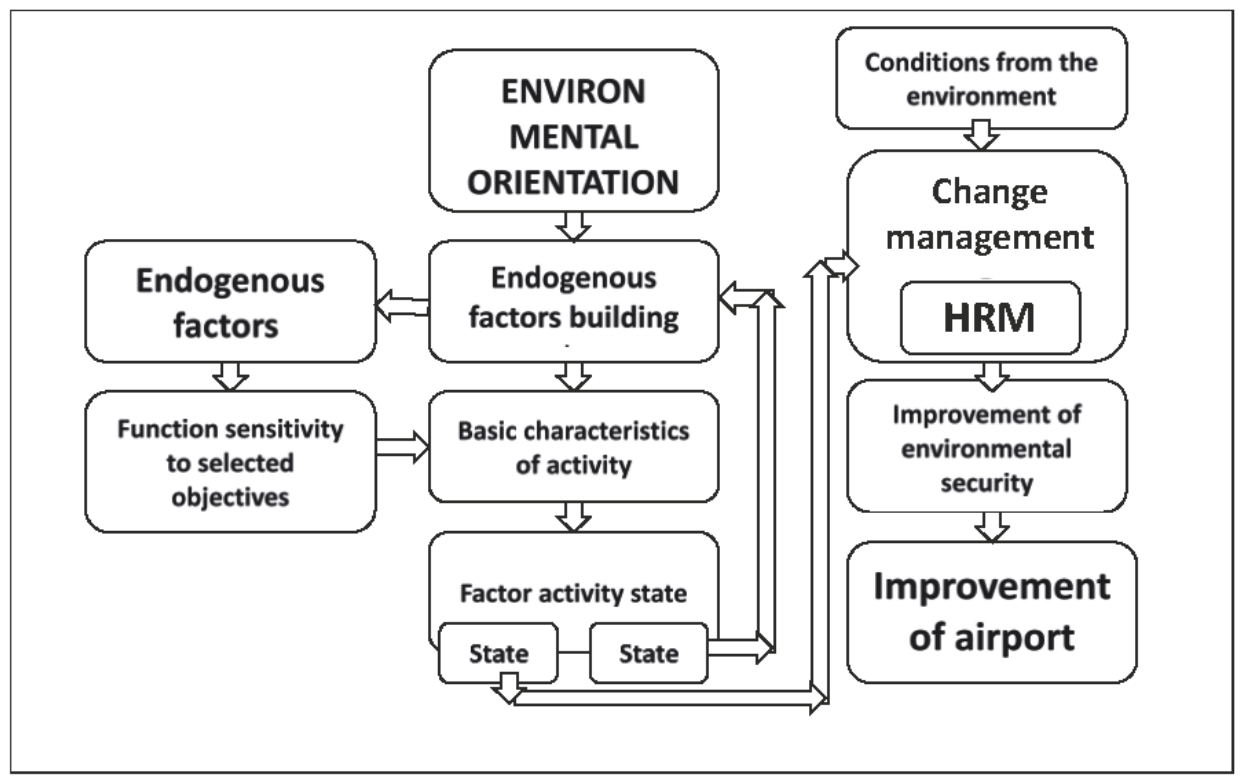

Fig. 2. Model of airport environmental orientation algorithm

In the zones of influence (cf. fig. 1), the ordered factors creating environmental potential which come from endogenous sources were assumed to be elements of three sets; administration (AD), management (MA) and airport technical process service (TPS). Correlations between elements of the above-mentioned sets will be specific for each airport analyzed, in each case, however, there will be such elements that will constitute the product of those sets. The common part of the sets will create a separate set of correlated elements (fig. 1). The level of environmental competence depends on the strength of connections between endogenous factors of the airport.

The degree of correlation of factors can be determined by examining how many elements of a given set share at least one correlation with elements of the other set. The degree of correlation between the entire sets will be the arithmetic mean of the number of correlations between the sum of elements from a given set and the sum of elements from other sets. The term "correlation" is to be understood as environmental interaction rather than dependence.

Solving the problem requires, first of all, ordering the system structure by determining what elements are in each set that will be subject to examination. The examination of environmental competence of airports requires the evaluation of minimum two competencebuilding factors in each of the above-mentioned sets. 
The following factors were classified as fundamental:

- in the AD set: the environmental hazard recording system, the ongoing analysis of environmental protection data system, and the environmental protection status monitoring system,

- in the MA set: the system of selective waste sorting, transfer and storage, and the reverse logistics of waste,

- in the TPS set: environmental protection infrastructure and infrastructure for the reverse logistics of waste.

Factors which affect environmental potential have to be brought to the necessary activity level, whose characteristics are determined by the identity [5].

$\frac{\text { Number of factors }}{\text { Time }}+\frac{\text { Number of factors }}{\text { impact range }}=\frac{\text { impact range }}{\text { Time }}$

The company's environmental orientation algorithm assumes three states describing the activity of factors coming from endogenous sources of the building potential, namely:

- state 0 - no activity

- state 1 - ineffective activity

- state 2-maximum activity at the self-organization level

Diagnostic tests according to the methodology adopted allowed for the analysis of the structure of interdependent factors, which were grouped by ranking in three spheres of influence:

- administration,

- management,

- technical process service.

Table 1

List of negative deviations in the activity of factors coming from endogenous sources of environmental potential

\begin{tabular}{||l|l|l|l||}
\hline No. & \multicolumn{1}{|c|}{ Negative deviations } & Diagnostic tests' area & $\begin{array}{c}\text { Mean activity } \\
\text { level }\end{array}$ \\
\hline 1 & $\begin{array}{l}\text { In the airport management system, } \\
\text { ecology is treated as a secondary matter }\end{array}$ & Management system & 1 \\
\hline 2 & $\begin{array}{l}\text { There is a minimization of the approach } \\
\text { to statutory obligations within the scope } \\
\text { of the airport environmental security }\end{array}$ & Management system & 1 \\
\hline 3 & $\begin{array}{l}\text { Lack of management procedures } \\
\text { concerning waste reverse logistics }\end{array}$ & Airport security & 0 \\
\hline 4 & $\begin{array}{l}\text { Lack of advanced care for } \\
\text { environmental security in airport } \\
\text { operation processes }\end{array}$ & Airport security & 1 \\
\hline
\end{tabular}




\begin{tabular}{||l|l|l|l||}
\hline 5 & $\begin{array}{l}\text { Interventional nature of the work in the } \\
\text { field of environmental protection }\end{array}$ & Airport administration & 1 \\
\hline 6 & $\begin{array}{l}\text { Weak correlation between waste and } \\
\text { recycling }\end{array}$ & Airport economics & 0 \\
\hline 7 & $\begin{array}{l}\text { Lack of economic efficiency in waste } \\
\text { management }\end{array}$ & Airport economics & 0 \\
\hline 8 & $\begin{array}{l}\text { Waste collection companies are made } \\
\text { responsible for the environmental } \\
\text { security ofthe airport }\end{array}$ & $\begin{array}{l}\text { Contracts with service } \\
\text { providers }\end{array}$ & 1 \\
\hline 9 & $\begin{array}{l}\text { Poor awareness of all employees with } \\
\text { regard to the environmental security of } \\
\text { the airport }\end{array}$ & $\begin{array}{l}\text { Human resource } \\
\text { management }\end{array}$ & 1 \\
\hline
\end{tabular}

The table presents a summary of the factors extracted using diagnostic tests from endogenous sources of creating the environmental potential of airports, and those that ensure the achievement of the objectives set for the environmental orientation. A relatively low level of activity (averaged for the examined airports) is visible in the areas described, as well as a total lack of activity concerning waste reverse logistics. The lack of management procedures regarding reverse logistics leaves too much freedom in its implementation in relation to the restrictions due to ensuring airport security.

The other negative deviation is the lack of a business approach to waste management, and this fact seems to be related to the poor economic motivation with respect to that issue in the context of ownership supervision.

\begin{tabular}{|c|c|c|c|c|c|c|c|}
\hline \multirow{3}{*}{$A D$} & Employees'environmentalawareness & & & & & & \\
\hline & Procedures & $2^{\circ}$ & $2^{\circ}$ & $2^{\circ}$ & & & \\
\hline & Airport management supervision & $3^{\circ}$ & $3^{\circ}$ & $1^{\circ}$ & & & \\
\hline \multirow{5}{*}{ MA } & Significance of environmental security & $1^{\circ}$ & $1^{\circ}$ & $2^{\circ}$ & $3^{\circ}$ & $4^{\circ}$ & $2^{\circ}$ \\
\hline & Motivation system & $3^{\circ}$ & $3^{\circ}$ & $1^{\circ}$ & $3^{\circ}$ & $2^{\circ}$ & $3^{\circ}$ \\
\hline & Involvement & $3^{\circ}$ & $4^{\circ}$ & $4^{\circ}$ & $4^{\circ}$ & $2^{\circ}$ & $1^{\circ}$ \\
\hline & & 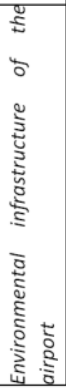 & 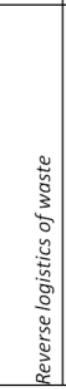 & 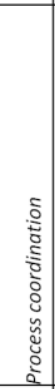 & 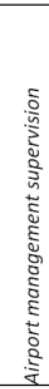 & 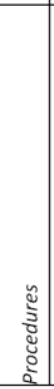 & 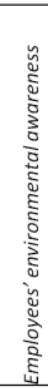 \\
\hline & & \multicolumn{3}{|c|}{ TPS } & \multicolumn{3}{|c|}{$A D$} \\
\hline
\end{tabular}

Fig. 3. Matrix of average correlation values between the factors building environmental competences of the airports under examination 


\section{Conclusion}

The above-mentioned tests performed using the diagnostic method showed that the range of the areas discussed differs significantly. At some airports, the influence of a given area was so insignificant that there were no effects of it at all.

Despite meeting their statutory obligations, the airports examined possess mediumlevel environmental competences. The evidence of this is the correlations between the elements of sets containing the factors of building environmental competences (cf. fig. 3 ). The correlation between the elements of the MA set with the elements of the AD set reached an average value of 2.6, the correlation of the AD set with those of the TPS set is at the level of 2.5. The lowest value - only 2.4 - was reached in the correlation between the elements of the MA and TPS sets

In order for the airport operation security not to be burdened by ecology, and especially by waste reverse logistics, the correlations between the endogenous factors for building environmental competences should reach an average value close to 4.0.

The research studies performed also showed a weak relationship between the problem of waste and the recycling revenues, and, especially, the lack of a direct relationship which arises from the planning and implementation of recycling revenues. The solution adopted by most airports is "to get rid of the waste problem", most frequently by making contracts with service subcontractors; these are municipal or other specialist companies operating on the local market. The contracts contain the terms of paid and unpaid services, or barter transactions (as in the case of cutting grass). Paid services are mainly related to municipal waste.

\section{References}

1. Fajczak-Kowalska A.: Wybrane aspekty logistyki zwrotnej Logistyka, No. 6, 2014.

2. Greve C., Davis J.: An Executive's Guide to Reverse Logistics. How to Find Hidden Profits by Managing Returns. Greve-Davis, 2012.

3. Korzeniowski A., Skrzypek M.: Ekologistka zużytych opakowań. ILiM, Poznań 1999.

4. Kunert O.: Podnoszenie jakości logistyki lotnictwa poprzez rozwój kompetencji zawodowych menedżerów. ZN WSOSP, Dęblin 2015.

5. Kunert O.: Budowa kompetencji innowacyjnych wyzwaniem rozwojowym polskich przedsiębiorstw. Monografie PŁ, Łódź 2008.

6. Pinna R., Carrus P.P.: Reverse Logistics and the Role of Fourth Party Logistics Provider. In: Groznik A., Xiong Y. (eds.), Pathways to Supply Chain Excellence, InTech, 2012.

7. Sadowski A., Ekonomiczne i ekologiczne aspekty stosowania logistyki zwrotnej w obszarze wykorzystania odpadów. Wydawnictwo Uniwersytetu Łodzkiego, Łodź 2010. 
8. Szkoda M., Gajewska T.: Logistyka zwrotna jako nowoczesna forma gospodarki odpadami, www.researchgate.net

9. Szołtysek J.: Logistyka zwrotna. Reverse Logistics. ILiM, Poznań 2009.

10. Tibben-Lembke R.S., Rogers D.S.: Differences between forward and reverse logistics. Supply Chain Management: An International Journal, Vol. 7, No. 5, 2002.

11. Urban K., Zabezpieczenie logistyczne służb utrzymania lotniska. In: Współczesne problemy logistyki lotnictwa. Teoria i praktyka, WSOSP 2015.

12. Vaz C.: Some Reasons to Implement Reverse Logistics on Companies. In: International Journal of Environmental Technology and Management, Vol. 16, No. $5 / 6,2013$.

13. Verstrepen S., Cruijssen F., Brito M.P., Dullaert W.: An Exploratory Analysis of Reverse Logistics in Flanders. European Journal of Transport and Infrastructure Research, Vol. 7, No. 4, 2007. 